\title{
TREATMENT OF TRIPLANE FRACTURE ANKLE FRACTURES ASSOCIATED WITH IPSILATERAL TIBIAL FRACTURES USING A NOVEL APPROACH
}

\section{FRATURA TRIPLANAR DO TORNOZELO CONCOMITANTE A FRATURA IPSILATERAL DA TÍBIA. UMA NOVA ABORDAGEM}

\author{
Weverley Rubele Valenza ${ }^{1}$ (1), Jamil Faissal Soni ${ }^{1}$ (i), Jean Carlo Barbosa ${ }^{1}$ (i), Christiano Saliba Uliana ${ }^{1}$ (i), \\ CAROLINA UMETA MATSUNAGA ${ }^{1}$ (1)
}

1. Hospital do Trabalhador, Curitiba, PR, Brazil.

\section{ABSTRACT}

Objective: The aim of this study is to purpose a novel approach to the concomitant triplanar and tibial shaft fracture. Methods: Retrospective study between 2001 and 2019. We collected the patients' general information, clinical and radiographic data, and complications after the following three-step treatment: (1) fixation of the Salter-Harris II fracture of the triplane fracture, (2) fixation of the Salter-Harris II/IV fracture with cannulated screws, and (3) fixation of the tibial fracture with flexible titanium nails. Results: The study included seven patients (six males) with a mean age of 14 years and a mean follow-up of 6.4 years (minimum two years). Five triplane fractures had two fragments and two had three fragments. Five fractures were classified as Salter-Harris II and two as Salter-Harris IV. Three tibial fractures were long oblique, three were spiral, and one had a third fragment. Six fractures affected the middle third and one affected the distal third of the tibia. All triplane and tibial fractures consolidated without significant displacement. No physeal damage was identified. Conclusions: This study described the association of tibial fractures with triplane ankle fractures managed by our proposed treatment, which proved to be effective for this fracture association. Level of Evidence IV, Case Series.

Keywords: Tibial Fracture. Ankle Fracture. Fracture Fixation, Internal. Salter- Harris Fractures.

\section{RESUMO}

Objetivo: Propor uma nova abordagem para fraturas concomitantes da diáfise da tíbia e triplanares do tornozelo. Métodos: Estudo retrospectivo entre 2001 e 2019. Foram coletadas informações gerais: dados clínicos, radiográficos e complicações. As fraturas seguiram três passos no tratamento: (1) fixação do fragmento Salter-Harris tipo III da fratura triplanar; (2) fixação do fragmento Salter-Harris II/IV com parafuso canulado; e (3) fixação da fratura diafisária da tíbia com hastes flexíveis. Resultados: O estudo incluiu sete pacientes (seis homens) com idade média de 14 anos e seguimento médio de 6.4 anos (mínimo de dois anos). Cinco fraturas triplanares tinham dois fragmentos principais e duas tinham três fragmentos. Cinco fraturas na radiografia em perfil foram classificadas como Salter-Harris II e duas como Salter-Harris IV. Três fraturas diafisárias tibiais tinham traço obliquo longo, três traço espiral e uma fratura com terceiro fragmento. Seis fraturas eram do terço médio e uma fratura do terço distal da tíbia. Todas as fraturas triplanares e tibiais consolidaram sem desvio significativo e não tivemos nenhuma lesão fisária. Conclusão: O estudo descreveu a associação da fratura da tíbia com a fratura triplanar do tornozelo e nossa proposta de tratamento, que se mostrou uma boa opção no tratamento dessa fratura especial. Nível de Evidência IV, Série de casos.

Descritores: Fratura Tibial. Fratura de Tornozelo. Fixação interna de Fraturas. Fratura Salter Harris.

Citation: Valenza WR, Soni JF, Barbosa JC, Uliana CS, Matsunaga CU. Treatment of triplane fracture ankle fractures associated with ipsilateral tibial fractures performing a novel approach. Acta Ortop Bras. [online]. 2021;29(6):323-326. Available from URL: http://www.scielo.br/aob.

\section{INTRODUCTION}

The tibia is the third long bone most frequently affected by fractures at any age during childhood and adolescence. The distal third is the most commonly involved tibial portion, followed by the middle third. Regarding the type of fracture line, the most prevalent is the oblique line, followed by multifragmented fractures and fractures with transversal lines; the spiral fracture line is the least common. The most frequent fractures associated with tibial fractures are ankle fractures. ${ }^{1}$

Most tibial fractures are adequately treated with a conservative approach using long-leg casting, but closed reduction may be required in the presence of displacement. Surgical treatment is recommended in open fractures, polytrauma patients, "floating"

All authors declare no potential conflict of interest related to this article.

The study was conducted at Hospital do Trabalhador.

Correspondence: Weverley R. Valenza. Av. Iguaçu, 2960, Curitiba, Paraná, Brazil, 80240031. weverleyvalenza@yahoo.com 
knee, loss of reduction, irreducible fractures, or in cases associated with other fractures in the same segment.

Triplane ankle fractures are infrequent, corresponding to $7 \%$ of all ankle fractures according to Spiegel et al. ${ }^{2}$ These fractures occur during adolescence, due to the characteristic asymmetric closure of the tibial physeal plate in this age group, which starts from the central portion of the plate and extends to the posteromedial and anterolateral aspects of the plate.

Cooperman et al. described the mechanism of trauma involved in triplane fractures as "twisting in external rotation". ${ }^{3}$ These fractures are usually characterized by the presence of Salter-Harris type III epiphyseal fracture-detachment in anteroposterior radiographic views and type II or IV fractures in lateral views. Triplane fractures have several subtypes with two, three, or four fragments and are described as intramalleolar or extramalleolar; however, all subtypes follow the same configuration pattern described above. ${ }^{4}$ Fractures with a displacement of up to $2 \mathrm{~mm}$ are generally treated conservatively, whereas those with larger displacements must be reduced and, if possible, undergo fixation. ${ }^{5}$ The association of triplane fractures with ipsilateral tibial fractures is uncommon, occurring at an incidence of $8.5 \%$, according to Rapariz et al. ${ }^{6}$

This study aims to report the infrequent association of triplane fractures and ipsilateral tibial fractures and analyze the outcomes after treatment with a novel protocol adopted at our institution.

\section{MATERIALS AND METHODS}

This was a retrospective analysis of medical records level IV, of patients with triplane ankle fractures associated with ipsilateral tibial fractures, treated at a tertiary trauma hospital between January 2001 and January 2019, and with a minimum follow-up of 2 years. We collected information regarding the patients' sex and age, mechanism of trauma, fracture classification (with the triplane fractures described considering the number of fragments and the tibial fractures according to the fracture line and location) and initial deviation of the triplane fracture by axial computerized tomography. Data regarding clinical and radiographic results and complications were obtained from the patients' medical records.

All patients underwent surgery following the same three-step technique protocol:

First step: treatment of the triplane fracture with closed reduction and percutaneous fixation of the Salter-Harris III fracture visualized in the anteroposterior view with a cannulated screw from a lateral to a medial direction to correct the joint deviation.

Second step: fixation of the Salter-Harris II or IV fragment visualized in the lateral view with one or two percutaneous screws positioned from an anterior to posterior direction.

Third step: fixation of the tibial fracture with two titanium flexible intramedullary nails from a proximal to a distal direction, C-shaped, one introduced laterally and the other medially at the proximal tibial metaphysis (Figures 1, 2, 3, 4).

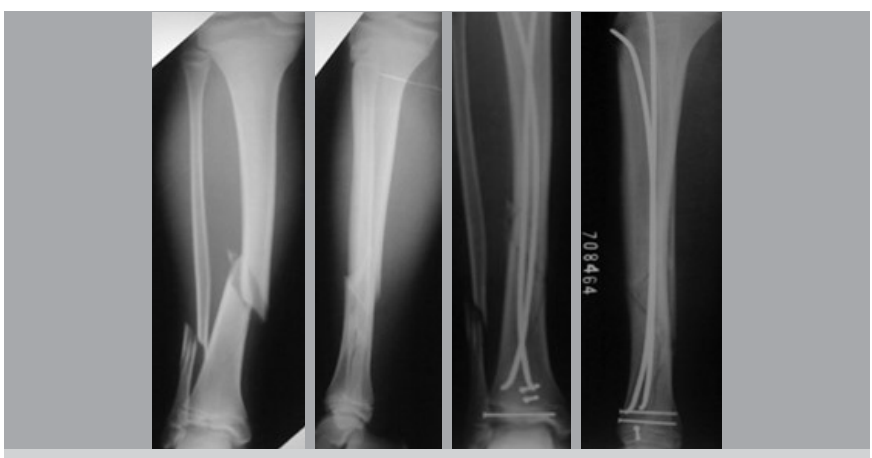

Figures 1, 2, 3 e 4: Pre and postoperative x-rays, association of tibial and triplane fracture treated with titanium elastic nail for tibial and cannulated screws for triplane fractures.
Post-operative care: No orthesis such as splint or cast were used in any case. The patients could parcial weight bear (touchdown) during the first four weeks. Progressive weight bearing was allowed from the fourth week to total weight bearing after fracture union. The exclusion criteria were patients with incomplete medical records or tibial physeal closure, and those treated with a different surgical technique than the one described above.

The study was approved by the Research Ethics Committee (CAAE: 13435519.4.0000.5525) according to the National Health Council Resolutions 196/96 and 251/97.

\section{RESULTS}

Between January 2001 and January 2019, seven skeletally immature patients with triplane fractures associated with ipsilateral tibial fractures were treated following the steps detailed in the proposed protocol.

Six patients were males, and one was female, and the mean age of the cohort was 14 years old (range 13 to 16 years old). The fractures resulted from trauma associated with car (three cases) and bicycle (one case) accidents, and soccer (two cases) and basketball (one case) activities. The mean follow-up was 6.4 years (range 2 to 12 years).

Among the triplane fractures, five had two fragments (one of which was intramalleolar) and two had three fragments. On lateral x-rays, five fractures were classified as Salter-Harris II and two as Salter-Harris IV.

Among the tibial fractures, three were long oblique, three were spiral, and one had a third fragment. Six fractures were in the middle third and one in the distal third of the tibia (Table 1).

\begin{tabular}{c|c|c|c|c|c|c}
\multicolumn{7}{c}{ Table 1: General dates from pacients in this study. } \\
\hline Patient & Gender & Age & $\begin{array}{c}\text { Mechanism } \\
\text { of trauma }\end{array}$ & $\begin{array}{c}\text { Tibial fracture } \\
\text { type }\end{array}$ & $\begin{array}{c}\text { Triplane } \\
\text { fracture }\end{array}$ & $\begin{array}{c}\text { Follow } \\
\text { up }\end{array}$ \\
\hline 1 & Male & 13 & Soccer & Long oblique & 2 fragments & 3 years \\
\hline 2 & Male & 15 & $\begin{array}{c}\text { Bicycle } \\
\text { accident }\end{array}$ & Spiral & 2 fragments & 5 years \\
\hline 3 & Male & 13 & basketball & Long oblique & 3 fragments & 7 years \\
\hline 4 & Male & 14 & Car accident & Spiral & 3 fragments & 2 years \\
\hline 5 & Male & 14 & Car accident & Third fragment & 2 fragments & 6 years \\
\hline 6 & Female & 13 & Soccer & Long oblique & 2 fragments & 12 years \\
\hline 7 & Male & 16 & Car accident & Spiral & 2 fragments & 10 years \\
\hline
\end{tabular}

All triplane and tibial fractures consolidated. The final radiographic control showed no varus, valgus, antecurvatum, or recurvatum deformities greater than 5 degrees in the tibial fractures. In triplane fractures, we identified no physeal injuries or ankle joint deviations. During follow-up, one patient complained of ankle pain and edema during physical activities.

All flexible nails were removed as soon as the fractures were completely consolidated in at least three cortical surfaces and the integrity of the medullary cavity was recovered. No refractures of the tibial diaphysis were observed. The cannulated screws of the triplane fractures were not removed in any of the patients.

\section{DISCUSSION}

Isolated triplane ankle fractures are not common in childhood, but are well established and described. In contrast, their association with ipsilateral tibial fractures, which is quite unusual, has been reported in few studies. In our literature search, we found only five studies describing this association, with the largest 
series, including six patients. ${ }^{7-11}$ Despite the infrequency of this association, more studies are needed to compare treatments and establish the best approach.

Kasture and Azurza, ${ }^{12}$ in a case report and literature review, described that those tibial fractures may be oblique or spiral (suggesting a twisting injury), while triplane fractures also result from traumas with this type of mechanism, postulating that the trauma extends distally from the leg to the ankle. These authors also point out that if the trauma started at the ankle and continued to the tibia, the displacement of the triplane fracture would be greater than that usually observed. The authors also suggest that the trauma involves greater energy to result in fracture of both the tibia and ankle. The fractures found in our patients confirms the description of these authors.

The same authors recommend that a concomitant ankle fracture should be excluded with radiographic evaluation in adolescents with spiral or oblique tibial fractures, an important precaution to ensure that no injury is left unnoticed.

The first treatment step was the fixation of the Salter-Harris type III fragment visualized in the anteroposterior view; if the patients had a displacement of $2 \mathrm{~mm}$ or more, this initial displacement could be treated with closed reduction and percutaneous fixation with a cannulated screw.

The option to start the treatment at the ankle instead of the tibia was based on our concern that the manipulation or fixation of the tibial fracture could increase the displacement of the triplane fracture, transforming a fracture with little displacement into a displaced fracture requiring open reduction.

The second step was the fixation of the Salter-Harris II or IV fragment, with one or two cannulated screws from an anterior to a posterior direction, as customarily done in the treatment of isolated triplane fractures.

The third step included closed reduction and fixation of the tibial fracture with flexible titanium nails, a step that could be performed without risk of affecting the ankle fracture.

In general, tibial fractures in children are treated conservatively. However, there is a trend in the literature towards the surgical approach in cases of fractures affecting teenagers, open fractures, highly dislocated fragments, polytrauma and concomitant or associated fractures. There is no gold-standard method of fixation of tibial fractures in children. Several options have been described in the literature, each one presenting their own advantages and downsides. Reports show shorter operative times and lower rates of wound complications when the tibial shaft fracture is fixed with a titanium flexible intramedullary nail. ${ }^{13,14}$

In cases of tibial fractures associated with triplane ankle fractures, studies in the literature describe many treatments for the tibial fracture, and fixation of cannulated screws for the triplane fractures. Holland et al. treated four tibial fractures with closed reduction and casting and one with external fixation ${ }^{15}$ Kasture and Azurza performed a minimally-invasive percutaneous $3.5 \mathrm{~mm}$ locking plate fixation to treat the tibial fracture. ${ }^{12}$ Sprenger De Rover et al. treated the tibial fracture with closed reduction and fixation with plate and screws, ${ }^{16}$ whereas Jarvis and Miyanji treated tibial fractures with cast immobilization. ${ }^{17}$ Cuzmar-Grimalt et al. treated both the tibial and fibular fractures with locking plates. ${ }^{7}$

Different than the approach in these five studies, we treated the tibial fractures in our patients with flexible titanium nails. Advantages of these nails include percutaneous insertion, good stability and alignment, satisfactory cosmetic results, and facilitation of soft tissue care. However, removal of the nails is usually required, and in our study, all nails were removed (Figures $5,6,7,8,9,10$ ).

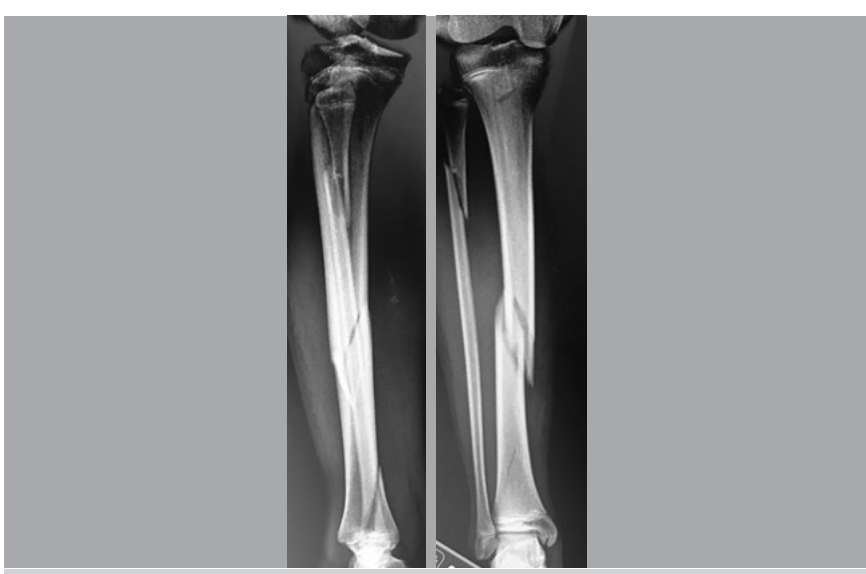

Figures 5, 6: Association of tibial and triplane fracture.

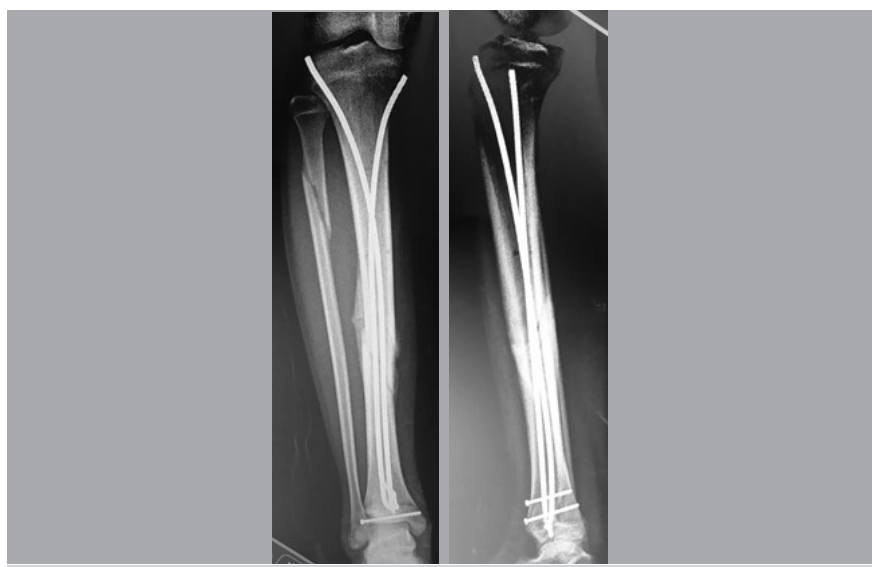

Figures 7, 8: One month after titanium elastic nail for tibial and cannulated screws for triplane fractures.

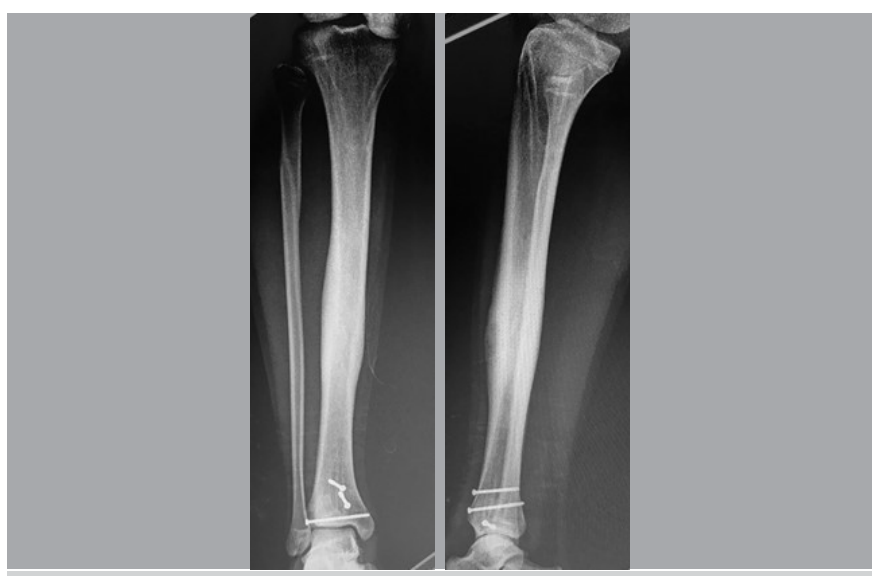

Figures 9, 10: After titanium elastic nail removal.

As limitation, we cite the retrospective nature of our study and the small size of the sample. As a major strength, the fact that all patients were treated following the same protocol.

\section{CONCLUSIONS}

Our study described the association of tibial fractures with triplane ankle fractures treated with a novel protocol comprising initial fixation of the triplane ankle fracture with cannulated screws followed by fixation of the tibial fracture with flexible titanium rods. This approach proved to be effective in the treatment of this fracture association. 
AUTHORS' CONTRIBUTIONS: Each author contributed individually and significantly to the development of this article. WRV: study conception and design study writing, review and critical review, surgeries, data and statistical analysis; JCB: study conception and design, study writing and review, data collection and analysis, statistical analysis; JFS: surgeries, study review, data analysis, final approval of the manuscript to be published; CSU: surgeries, study writing and review; CUM: study writing and review, data collection and analysis, statistical analysis.

\section{REFERENCES}

1. Nicoll EA. Fractures of the tibial shaft. A survey of 705 cases. J Bone Joint Surg Br. 1964 Aug;46:373-87.

2. Flynn JM, Skaggs DL, editors. Rockwood and wilkins' fractures in children. $8^{\text {th }}$ ed. Philadelphia: LWW; 2014.

3. Spiegel PG, Cooperman DR, Laros GS. Epiphyseal fractures of the distal ends of the tibia and fibula. A retrospective study of two hundred and thirty-seven cases in children. J Bone Joint Surg Am. 1978 Dec;60(8):1046-50.

4. Cooperman DR, Spiegel PG, Laros GS. Tibial fractures involving the ankle in children. The so-called triplane epiphyseal fracture. J Bone Joint Surg Am. 1978 Dec;60(8):1040-6.

5. Von Laer L. Classification, diagnosis, and treatment of transitional fractures of the distal part of the tibia. J Bone Joint Surg Am. 1985 Jun;67(5):687-98.

6. El-Karef E, Sadek HI, Nairn DS, Aldam CH, Allen PW. Triplane fracture of the distal tibia. Injury. 2000 Nov;31(9):729-36.

7. Holland TS, Prior CP, Walton RD. Distal tibial triplane fracture with ipsilateral tibial shaft fracture: A case series. Surg J R Coll Surg Edinb Irel. 2018 Dec;16(6):333-8.

8. Sprenger De Rover WB, Alazzawi S, Hallam PJ, Walton NP. Ipsilateral tibial shaft fracture and distal tibial triplane fracture with an intact fibula: a case report. J Orthop Surg Hong Kong. 2011 Dec;19(3):364-6.

9. Jarvis JG, Miyanji F. The complex triplane fracture: ipsilateral tibial shaft and distal triplane fracture. J Trauma. 2001 Oct;51(4):714-6.
10. Kasture S, Azurza K. Triplane ankle fracture with concomitant ipsilateral shaft of tibia fracture: case report and review of literature. J Orthop Case Rep. 2017 Jun;7(3):84-7.

11. Cuzmar-Grimalt D, Escudero-Heldt M, Aldunate-González JT, Plaza-Guzmán N. Ankle fracture in adolescents: triplanar injury associated to fracture of leg. Acta Ortop Mex. 2016 Jun;30(3):144-6.

12. Shin AY, Moran ME, Wenger DR. Intramalleolar triplane fractures of the distal tibial epiphysis. J Pediatr Orthop. 1997 Jun;17(3):352-5.

13. Pennock AT, Bastrom TP, Upasani VV. Elastic intramedullary nailing versus open reduction internal fixation of pediatric tibial shaft fractures. J Pediatr Orthop. 2017 Nov;37(7):e403-8.

14. Cruz AI, Raducha JE, Swarup I, Schachne JM, Fabricant PD. Evidence-based update on the surgical treatment of pediatric tibial shaft fractures. Curr Opin Pediatr. 2019;31(1):92-102.

15. Feldman DS, Otsuka NY, Hedden DM. Extra-articular triplane fracture of the distal tibial epiphysis. J Pediatr Orthop. 1995 Aug;15(4):479-81.

16. Crawford $\mathrm{AH}$. Triplane and tillaux fractures: is a $2 \mathrm{~mm}$ residual gap acceptable? J Pediatr Orthop. 2012 Jun;32(Suppl 1):S69-73.

17. Rapariz JM, Ocete G, González-Herranz P, López-Mondejar JA, Domenech J, Burgos J, et al. Distal tibial triplane fractures: long-term follow-up. J Pediatr Orthop. 1996 Feb;16(1):113-8. 